\title{
Paris in London, or the major research journals in foreign languages
}

\section{Udo Jung}

The author discusses possible criteria for assessing foreign-language journals and comments on the difficulties which arise. He dedicates the article to John Trim, former Director of the Centre for Information on Language and Research (CILT), and pays tribute to their quarterly abstracting journal, LANGUAGE TEACHING, which over the past 18 years has been assessing international foreign-language journals. He makes a critical assessment of the method used by CILT and by means of a number of tables he elucidates the criteria used in ranking the journals, their authors, and their countries of origin.

Die skrywer bespreek moontlike kriteria wat gebruik kan word vir die evaluering van vreemde taal-joernale en lewer kommentaar op probleme wat opduik. Hy dra die artikel op aan John Trim, voormalige Direkteur van die Centre for Information on Language and Research (CILT) en bring hulde aan hulle kwartaallikse abstrakte-joernaal, LANGUAGE $T E A C H I N G$, wat die afgelope 18 jaar reeds internasionale vreemde taal-joernale evalueer. Hy bespreek metodes wat CILT gebruik krities en met behulp van 'n aantal tabelle verklaar hy die kriteria wat gebruik word om joemale, hulle outeurs en die lande van oorsprong te rangskik.

What is an important journal? What are the important journals in foreign languages? Assessing the quality of foreign-language journals is no easy matter. Much depends on perspective: the practising language teacher needs help to carry him through the day; the school administrator prefers journals with a touch of officialdom to ensure the smooth running of the machinery called education; the researcher needs a much broader perspective. He stands in the centre of intersecting lines of scientific endeavour: data as well as methods from linguistics and psychology, from anthropology and pedagogy, from literary scholarship and the social sciences must be taken in and adapted. No single journal can cater for all these needs simultaneously, although there are countries with only one of official foreign-language journal to their names. In the Western world, however, a multiplicity of journals vie for the teacher's attention. But "there seems to be no clearly marked hierarchy of prestige" (Matthey 1967:1) among them. Yet this is what is needed. McGlone and associates (1985) point out that humanities professors must compete for funds with researchers from other disciplines. They must, one might add, judiciously dispose of their time. Only journals of immediate relevance to their special field can lay claim to their attention. To communicate with researchers around the world, they must publish in the "right" journals. Otherwise their paper will fall among the thorns. Publishers and editors also keep an eye on the journals market to see whether their territories are being invaded by rivals in the field. What is the formula that spells success in an expanding EFL market? 


\section{PREVIOUS RESEARCH}

In 1985 McGlone et al. attempted to establish the journal hierarchy, which they had found to be missing, by sending questionnaires to 399 heads or chairs of doctora degree granting programmes. Although their feedback rate eventually rose to an impressive 47 percent, they came to the conclusion that "more research is needed if an answer is to be found to the question" (McGlone 1985:5).

Researchers prospecting in uncharted territories usually turn their heads to see whether their predecessors may have left any traces. In our case, we hit upon only a few unconnected descriptions of journals. These are a useful feature of information dissemination in countries with limited amounts of foreign currency. The year's crop is assessed by a knowledgeable scholar and passed on in condensed form to his less fortunate colleagues. Or a guru may size up a journal's production over a period of time for the benefit of his disciples. Beneke (1965) is an example of the first instance. Of more interest to our present concern are journal evaluations based on more than one volume. It might not be impossible to establish an evaluative grid, the cells of which are filled with bits of information culled from these reports. This is not our line of enquiry, but for the benefit of other researchers in the field, Table 1 (p.61) gives a number of references to books and journal articles describing and evaluating FL journals.

A more ambitious plan was followed by Lohmann (1976). The author compared a number of German foreign language journals over a long period of time. Strangely enough, the results were never published in any of the journals analysed, although - it is believed - quite a few of them were invited to do so. Reasons for declining to print the results of research such as Lohmann's could be methodological in nature. The comparability of journals can be called into question. Authors are accused of comparing apples with pears. Or their impartiality may be doubted. We shall, therefore, not follow Lohmann's example. Nor do we think that the methodology employed by McGlone (1985) should be copied.

\section{METHOD}

Instead of using a multiplicity of sources, a single judge, or a similar body, will be asked to hand "the apple" to whomever he thinks deserves the greatest praise. There is such a collective "Paris" in the British capital who has monitored foreign language journals for more than 18 years and published the results at regular intervals. I am referring to the Centre for Information on Language and Research (CILT), whose long-time director, John Trim, retired in 1987 and to whom this article is dedicated. CILT publishes a quarterly abstracting journal whose coverage is international and includes the major languages of the world: Language Teaching (formerly Language Teaching \& Linguistics: Abstracts). The journal differs from other bibliographic services in that it does not report on publications irrespective of their worth. Since the journal prints only between 294 (in 1975) and 679 (in 1984) abstracts per annum, a choice has to be made. Not more than a fraction of the articles published in the roughly 400 international journals that CILT has access to can be reported on in Language Teaching. CILT offers information on how the selection process is accomplished on the inside front cover of Language Teaching "The editor, members of the editorial board and CILT staff examine some 400 journais ... and select (my italics) the most significant articles which

* break new ground

* clarify a problem area

* give a useful review of earlier work 
* report important research findings

" $\quad$ present new and useful classroom methods and materials."

Table 1

Journal Name

Bibliographical Reference

American Speech

Anglo-Irish Studies

Die berufsbildende Schule

English Language Teaching Journal

Etudes Irlandaises

Special Language/Fachsprache

Le Français dans le Monde

Glottodidactica

Indian Journal of Applied Linguistics

Irish University Review

Journalism Quarterly

Eble (1985)

Otto (1978)

Strecker (1978)

Matthey (1967)

Otto (1978)

Spiegel (1988)

Birkenfeld (1988)

Moirand (1988)

Schröder (1985)

Bhatia (1978)

Otto (1978)

Gerlach (1988)

Language Learning

Henning (1986)

Diller (1977)

Language and Style

Otto \& Stratman (1977)

Literatur in Wissenschaft und Unterricht

Freudenstein (1987)

Neusprachliche Mitteilungen

Borchers (1986)

Reflet

Slavic and East European Journal

Kahn \& Sapin-Lignieres (1982)

Perkins \& Chvany (1987)

TESOL Quarterly

Henning (1986)

Swales (1988)

Zeitschrift f. Anlistik u. Amerikansistik

Diller \& Stratman (1978)

It could be argued that not all elements of subjectivity have been eliminated from this method of research. This is certainly true. At the same time the advantages outweigh possible shortcomings:

It is not an ad hoc method. On the contrary, the journals are seen in a historical perspective. Journal-watching for 18 years must have sharpened and consolidated the judgement of CILT staff considerably. Their article selection practices do mirror trends in the methodological discussion, as do, incidentally, journal names (take e.g. the Audiovisual Language Journal which was renamed the British Journal of Language Teaching in the early eighties.This is, of course, a reflection on the decline of audiovisual methods in the seventies). To capture changing attitudes, one can choose regular intervals or break points and ask what changes have occurred during the observation periods. This will be done in our case (cf. Table 2). Starting in 1968, our first break point will be after three years at the end of 1970. From then on we shall turn round, as it were, 
every five years and look back at our data to establish what kind of changes have occurred.

Table 2

\begin{tabular}{|c|c|c|}
\hline Volume/Year & Number of Entries & Period \\
\hline $\begin{array}{l}\text { Vol. } 1(1968) \\
\text { Vol. } 2(1969) \\
\text { Vol. } 3(1970)\end{array}$ & $\begin{array}{l}330 \\
359 \\
370\end{array}$ & I \\
\hline $\begin{array}{l}\text { Vol. } 4(1971) \\
\text { Vol. } 5(1972) \\
\text { Vol. } 6(1973) \\
\text { Vol. } 7(1974) \\
\text { Vol. } 8(1975)\end{array}$ & $\begin{array}{l}368 \\
368 \\
293 \\
285 \\
294\end{array}$ & II \\
\hline $\begin{array}{l}\text { Vol. } 9(1976) \\
\text { Vol. } 10(1977) \\
\text { Vol. } 11(1978) \\
\text { Vol. } 12(1979) \\
\text { Vol. } 13(1980)\end{array}$ & $\begin{array}{l}310 \\
365 \\
387 \\
401 \\
379\end{array}$ & III \\
\hline $\begin{array}{l}\text { Vol. } 14(1981) \\
\text { Vol. } 15(1982) \\
\text { Vol. } 16(1983) \\
\text { Vol. } 17(1984) \\
\text { Vol. } 18(1985)\end{array}$ & $\begin{array}{l}409 \\
509 \\
527 \\
679 \\
628\end{array}$ & IV \\
\hline
\end{tabular}

Once this has been accomplished, corroborative or counter evidence can be sought. Data from citation indices can be correlated with our findings and the name indices of data bases will prove to be invaluable sources of information. In some cases, however, negative correlations are predicted for the comparisons between the status of journals as measured by CILT and, the number of copies sold. There is only a limited amount of wisdom in numbers, but you can't fool all the people all the time, as Lincoln remarked more than one hundred years ago.

\section{RESULTS}

Of an estimated 115000 articles published by the 488 journals surveyed by CILT between 1968 and 1985, CILT staff selected a total of 7261 in 18 years or an average of 403 per annum for inclusion and annotation in Language Teaching. The journals are unevenly distributed in CILT's bibliographic service. Exactly 50 per cent of them do not occur more than 4 times in 18 years; 25 per cent only once; 19 per cent turn up between 5 and 10 times; 8,4 per cent of the journals appear between 11 and 18 times. A total of 69 per cent of all journals are thus represented between 1 and 18 times, i.e. once or less per 
annum. The top 20 journals, on the other hand, account for a total of 2595 entries; this is 35 per cent. But even among the top 20 we note a wide divergence; the success rate of the leading journal being 4 times that of the lowest ranking. This is shown in Table 3.

Table 3

\begin{tabular}{|llcccc|}
\hline $\begin{array}{l}\text { Total } \\
\text { number of } \\
\text { entries } \\
\text { in Language } \\
\text { Teaching }\end{array}$ & $\begin{array}{c}\text { Jear of } \\
\text { founda- } \\
\text { tion }\end{array}$ & $\begin{array}{c}\text { Numbers } \\
\text { per } \\
\text { volume }\end{array}$ & $\begin{array}{c}\text { Circu- } \\
\text { lation }\end{array}$ & $\begin{array}{c}\text { Accep- } \\
\text { tance } \\
\text { rate }\end{array}$ \\
\hline & & & & \\
318 & 1 ELT Journal & & & & \\
247 & 2 TESOL Quarterly & 1946 & 4 & 8500 & \\
188 & 3 Language Learning & 1967 & 4 & 8000 & \\
169 & 4 Le Français dans le Monde & 1948 & 4 & 3000 & \\
165 & 5 IRAL & 1961 & 8 & 15000 & \\
143 & 6 Linguistics & 1963 & 4 & 2000 & \\
133 & 7 Modern Language Journal & 1963 & 6 & 1200 & \\
125 & 8 Audiovisual Language Journal* & 1916 & 4 & 7200 & $10-13 \%$ \\
122 & 9 Die Neuern Sprachen & 1962 & $3 / 4$ & 2000 & \\
117 & 10 Canadian Mod. Lang. Rev. & 1952 & 6 & 5000 & \\
116 & 11 Lingua & 1944 & 4 & 3000 & \\
115 & 12 Deutsch als Fremdsprache & 1954 & 12 & 1100 & \\
89 & 13 System & 1964 & 6 & - & \\
81 & 14 Language & 1973 & 3 & 1000 & \\
79 & 15 Russkij Jazyk & 1925 & 4 & 7000 & \\
78 & 16 ITL Review & 1967 & 6 & - & \\
78 & 16 Modern Languages & 1968 & 4 & 600 & \\
78 & 16 Etudes de Linguistique Appliqué & 1905 & 4 & 3500 & \\
77 & 19 Linguistische Berichte & 1968 & 4 & - \\
77 & 19 Journal of Pragmatics & 1977 & 6 & - \\
\hline
\end{tabular}

* now British Journal of Language Teaching

Table 3 presents additonal information - if known - of the journals in question. The year a journal was founded can be an important item, if, as is the case with System e.g., the journal was founded after 1968. The journal is disadvantaged in comparison with others which were in existence during the whole period our survey covers.

A similar case could be made out for journals with only 3 issues per year. They are disadvantaged in comparison with those which publish double this number. It could be argued that a journal's frequency of occurrence in Language Teaching should be divided by the number of issues of that journal in order to counterbalance deficiencies and/or advantages. Knowledge of the number of articles per volume can also be useful to put the other item values in perspective. Circulation, too, is an important indicator of how much a journal is appreciated by its potential readership, whereas the acceptance rate tells us something about how much a journal is coveted by writers as an outlet for their research. 
Gains and Losses. Intuitively, and at first glance, the information displayed in Table 3 would seem satisfactory. On second thoughts, however, certain doubts crop up, the greatest being the apparent lack of dynamism in the booming market of foreign-language journals. In fighting their way to the top, some of the journals must have changed position in those 18 years. One can assume dogfights must have occurred. How can they be documented? By subdividing the 18 years between 1968 and 1985 into four smaller periods of nearly equal duration, it should be possible to highlight any changes that may have occurred. In tables 4 to 7 the resulting status changes can be observed.

Table 4

1st Period (1968 - 1970)

\begin{tabular}{|llr|}
\hline 1 & ELT Journal & 96 \\
2 & Modern Language Journal & 46 \\
3 & Language Learning & 32 \\
3 & IRAL & 32 \\
5 & Audiovisual Language Journal & 28 \\
6 & Russkij Jazyk za Rubezom & 27 \\
7 & Deutsch als Fremdsprache & 25 \\
7 & TESOL Quarterly & 25 \\
9 & Le Français dans le Monde & 22 \\
10 & Lingua & 16 \\
11 & Modern Languages & 12 \\
12 & The Canadian Modern Language Review & 10 \\
12 & Neuere Sprachen & 10 \\
12 & Linguistics & 10 \\
15 & Language & 5 \\
\hline
\end{tabular}

From the fact that only 15 of the 20 journals contained in Table 3 return in Table 4, it can be deduced that movement has occurred:

System was not in existence before 1973; Etudes de Linguistique Appliquée, although founded in 1962, did not come to the attention of CILT staff before 1974; ITL: $A$ Review of Applied Linguistics as well as Linguistsche Berichte was started in the same year as the abstracting journal; the Journal of Pragrnatics was not available before 1977.

With the exception of the Journal of Pragmatics, the top 20 banded together at the end of the second period, as can be seen from Table 5 (p.65).

The two most notable changes are those of TESOL Quarterly and Linguistics which leap into 2 nd and 5th position. The two journals continue to improve their rank during the next period of observation to the point of ousting the ELT Journal from its leading position. 
Table 5

2nd Period (1971 - 1975)

\begin{tabular}{|rlr|}
\hline 1 & ELT Journal & 133 \\
2 & TESOL Quarterly & 50 \\
3 & Le Fra Français dans le Monde & 49 \\
4 & Audiovisual Language Journal & 37 \\
5 & Linguistics & 35 \\
5 & The Modern Language Journal & 35 \\
7 & IRAL & 34 \\
8 & Deutsch als Fremdsprache & 33 \\
9 & Language Learning & 32 \\
10 & Modern Languages & 28 \\
11 & Die Neueren Sprachen & 24 \\
12 & Russkij Jazyk za Rubezom & 19 \\
13 & Lingua & 18 \\
14 & Language & 15 \\
15 & The Canadian Modern Language Review & 13 \\
16 & ITL Review & 10 \\
17 & Linguistische Berichte & 9 \\
18 & System & 5 \\
18 & Etudes de Linguistique Appliquée & 5 \\
\hline
\end{tabular}

Table 6

3rd Period (1976-1980)

\begin{tabular}{|lll|}
\hline 1 & TESOL Quarterly & 67 \\
2 & Linguistics & 54 \\
3 & ELT Journal & 46 \\
3 & Le Français dans le Monde & 46 \\
5 & The Canadian Modern Language Review & 44 \\
6 & IRAL & 42 \\
7 & Lingua & 39 \\
8 & Language Learning & 38 \\
9 & ITL Review & 36 \\
10 & System & 35 \\
11 & Audiovisual Language Journal & 33 \\
12 & Etudes de Linguistique Appliquée & 32 \\
12 & Linguistische Berichte & 32 \\
14 & Deutsch als Fremdsprache & 30 \\
15 & Die Neueren Sprachen & 26 \\
15 & Language & 26 \\
17 & Modern Language Journal & 25 \\
18 & Russkij Jazyk za Rubezom & 20 \\
19 & Modern Language & 18 \\
20 & Journal of Pragmatics & 16 \\
\hline
\end{tabular}


The ELT Journal continues to lose ground during the last period of observation as does Russkij Jayk za Rubezom which drops to 20 th rank from its leading position in the late sixties and early seventies. Table 7 shows what the situation looks like in the mideighties.

Table 7

4th Period (1981-1985)

\begin{tabular}{|rlr|}
\hline 1 & TESOL Quarterly & 105 \\
2 & Language Learning & 86 \\
3 & Die Neueren Sprachen & 62 \\
4 & Journal of Pragmatics & 61 \\
5 & IRAL & 57 \\
6 & Le Français dans le Monde & 52 \\
7 & The Canadian Modern Language Review & 50 \\
8 & System & 49 \\
9 & Linguistics & 44 \\
10 & ELT Journal & 43 \\
10 & Lingua & 43 \\
12 & Etudes de Linguistique Appliquée & 41 \\
13 & Linguistische Berichte & 36 \\
14 & Language & 35 \\
15 & ITL Review & 32 \\
16 & Audiovisual Language Journal & 27 \\
16 & Deutsch als Fremdsprache & 27 \\
16 & Modern Language Journal & 27 \\
19 & Modern Language & 20 \\
20 & Russkij Jazyk za Rubezom & 13 \\
\hline
\end{tabular}

Deutsch als Fremdsprache is also among the journals which showed a downward trend. It ought to be possible to catch upward and downward movement, gains and losses, in a single figure. This can be done by averaging the positions a journal obtains during the four observation periods. The procedure yields a weighted rank scale. The new rank scale is a more reliable measure of a journal's contribution to the collective wisdom of language teachers if one is willing to trust the judgement of CILT staff. 
Table 8

Weighted Rank Scale of the Top Twenty Journals Across the Whole Period of Observation (1968-1985)

\begin{tabular}{|c|c|c|c|c|}
\hline & & & \multicolumn{2}{|c|}{$\begin{array}{c}\text { Rank Losses(-) } \\
\text { Gains(+) } \\
\text { during } \\
1976-1986\end{array}$} \\
\hline 1 & TESOL Quarterly & 2.50 & + & + \\
\hline 2 & ELT Journal & 3.75 & - & - \\
\hline 3 & Language Learning & 5.25 & + & + \\
\hline 3 & Le Francais dans le Monde & 5.25 & - & + \\
\hline 5 & IRAL & 5.75 & + & + \\
\hline 6 & Linguistics & 7.00 & - & - \\
\hline 7 & Audiovisual Language Journal & 9.00 & - & - \\
\hline 8 & The Canadian Modern Language Review & 9.75 & + & - \\
\hline 9 & Lingua & 10.00 & + & - \\
\hline 9 & Modern Language Journal & 10.00 & - & + \\
\hline 11 & Die Neueren Sprachen & 10.25 & - & + \\
\hline 12 & Deutsch als Fremdsprache & 11.00 & - & - \\
\hline 13 & Journal of Pragmatics & 12.00 & & \\
\hline 13 & System & 12.00 & + & + \\
\hline 15 & ITL Review & 13.30 & + & - \\
\hline 16 & Etudes de Linguistique Appliquée & 14.00 & + & + \\
\hline 16 & Linguistische Berichte & 14.00 & + & + \\
\hline 16 & Russkij Jazyk za Rubezom & 14.00 & - & - \\
\hline 19 & Modern Languages & 14.25 & - & + \\
\hline 20 & Language & 14.50 & - & + \\
\hline
\end{tabular}

Column 4 of Table 8 indicates whether the journal in question was able to defend $(+)$ or improve on $(+)$ a position once obtained; minuses indicate losses. We can thus define losers and winners.

Losing journals are:

\section{ELT Journal}

Audio-Visual Language Joumal

Deutsch als Fremdsprache

Russkij Jazyk za Rubezom

The six winning journals are:

TESOL Quarterly

Language Learning

IRAL 


\author{
System \\ Etudes de Linguistique Appliquée \\ Linguistische Berichte
}

TESOL Quarterly, in the last-mentioned group, has recently been described by John Swales (1988) as a self-sufficing journal exclusively serving the needs of American TESOLers and TELFlers. Swales used the Social Sciences Citation Index to shed light on the question of how splendid the isolation of this journal from the rest of the world is. And indeed, for in-depth analyses of scientific journal, citation indices are an indispensable tool. It would be interesting to see how the top twenty interrelate with one another. But such an enormous task is beyond the scope of the present paper. How much is involved can be seen by the booklength account given by Moirand (1988) of Le Français dans le Monde or Heuer's comparison of German foreign-language journals.

To judge from the distribution of losers and winners, the centre of gravity in FLT has reverted to the United States.

Nomenclature. To see whether this is also the case in terms of authors' past and present position the name indices of Language Teaching have been exploited. Table 9 is a simple enumeration of authors as they occur in Language Teaching between 1968-1985, the cutoff point being arbitrarily set at more than five entries. 
Table 9

Frequency List of Authors in Language Teaching

\begin{tabular}{|c|c|c|}
\hline Name & Country & Frequency \\
\hline Swain, M. & $(\mathrm{CDN})$ & 15 \\
\hline Richards, J.C. & (USA) & 14 \\
\hline Helbig, $\mathrm{G}$. & (GDR) & 13 \\
\hline Littlewood, W.T. & (GB) & 12 \\
\hline Cohen, A.D. & (IL) & 11 \\
\hline Coste, D. & (F) & 11 \\
\hline Widdowson, H.G. & (GB) & 11 \\
\hline Brumfit, C.J. & (GB) & 10 \\
\hline Genesee, F. & (CDN) & 10 \\
\hline Stern, H.H. & (CDN) & 10 \\
\hline Cook, V.J. & $(\mathrm{GB})$ & 9 \\
\hline Krashen, S.D. & (USA) & 9 \\
\hline Taylor, B.P. & (USA) & 9 \\
\hline ZydatiB, W. & (FRG) & 9 \\
\hline Besse, $\mathrm{H}$. & (F) & 8 \\
\hline Butzkamm, W. & (FRG) & 8 \\
\hline Cruttenden, A. & $(\mathrm{GB})$ & 8 \\
\hline Dickerson, W.B. & (USÁ) & 8 \\
\hline Larsen-Freeman, D. & (USA) & 8 \\
\hline MacKay, R. & (CDN) & 8 \\
\hline Maley, A. & $(\mathrm{GB})$ & 8 \\
\hline Oller, J.W. jr. & (USA) & 8 \\
\hline Riley, P. & (F) & 8 \\
\hline Sampson, G. & (CDN) & 8 \\
\hline Seliger, H.W. & (USA) & 8 \\
\hline Valman, A. & (USA) & 8 \\
\hline Wode, $\mathrm{H}$ & (FRG) & 8 \\
\hline Giles, $\mathrm{H}$. & (GB) & 7 \\
\hline Holec, $\mathrm{H}$ & $(\mathrm{F})$ & 7 \\
\hline Hudson, $\mathrm{R}$ A. & (GB) & 7 \\
\hline Moirand, S. & (F) & 7 \\
\hline Palmer, A.S. & (GB) & 7 \\
\hline Tarone, E. & (USÁ) & 7 \\
\hline Beardsmore, H. Baetens & (B) & 6 \\
\hline Beattie, G.W. & (GB) & 6 \\
\hline Clark, E.V. & (USA) & 6 \\
\hline Comrie, $\mathrm{B}$. & (USA) & 6 \\
\hline Cummins, $\mathbf{J}$. & $(\mathrm{CDN})$ & 6 \\
\hline Davies, N.F. & (S) & 6 \\
\hline Fishman, J.A. & (ÚSA) & 6 \\
\hline Gaies, S.J. & (USA) & 6 \\
\hline Porquier, R. & $(\mathrm{F})$ & 6 \\
\hline Schachter, J. & (ÚSA) & 6 \\
\hline Snow, C.E. & (USA) & 6 \\
\hline Strevens, $\mathrm{P}$. & $(\mathrm{GB})$ & 6 \\
\hline Titone, $\mathbf{R}$. & (I) & 6 \\
\hline Tucker, R.G. & (USA) & 6 \\
\hline
\end{tabular}


Although it is notoriously difficult to attribute a nationality to certain writers who were born and raised in one country but later moved to another (the late David Stern is a classic example: born in Kassel (Germany) he was expatriated by the Nazis and moved to England where he taught for some time before he became the founder-director of the Modern Language Centre at OISE in Canada), there can be no question that the AngloSaxon countries, led by the US, are in the forefront of the methodology discussion. France and Germany who were on an equal footing with the United Kingdom at the, time of Passy and Viëtor have been dwarfed in comparison - if one is willing to trust the judgement of the London "Paris".

Table

Frequency List of Authors' Countries in Language Teaching

\begin{tabular}{|lc|}
\hline Country & Frequency \\
\hline USA & 121 \\
GB & 91 \\
CDN & 57 \\
F FRG & 47 \\
GDR & 25 \\
& 13 \\
\hline
\end{tabular}

If not, reasons must be adduced why and how the intuitively satisfactory lists produced by CILT should be altered to reflect better the situation of foreign language teaching in the world.

\section{BIBLIOGRAPHY}

ANON. 1983. Interview: Jack Richards discusses new LLC Journal. TESOL Newsletter $17,21$.

ANON. 1984. Are you in the charts? System $12317,318$.

BENEKE, G. 1965. Die Zeitschrift 'programmiertes lernen und programmierter unterricht' Jahrgang 1964. Fremdsprachenunterricht 9, 299-305.

BERTRAND, Y. 1984. Germanistische Zeitschriften in Frankreich. Info DaF 11, 56-64.

BHATIA, T.K. 1978. Indian Journal of Applied Linguistics. Intemational Review of Applied Linguistics in Language Teaching 16, 267-269.

BIRKENFELD, H. 1988. Special Language/Fachsprache. Internationale Zeitschrift für Fachsprachenforschung, -didaktik und Terminologie. Info DaF 15, 348-349.

BOGAARDS, P. 1986. Een veelzijdige voorlichting was het voortdurende streven. Levende Talen 411, 270-272. 
BORCHERS, H. 1986. Amerikanische Literatur- und Kulturkritik unter dem Einfluß der Psychoanalyse: das Beispiel der Zeitschrift Partisan Review. Anglistentag 1985 Paderbom. Ed. B. Carstensen \& H. Grabes. Gießen: Hoffmann Verlag, 273-287.

DILLER, H.-J. 1977. Language and Style. Anglistik \& englischunterricht 2, 209-221.

DILLER, H.-J. \& G. Stratman. 1978. Zeitschrift für Anglistik und Amerikanistik. Anglistik \& englischunterricht 5, 161-177.

EBLE, C. 1985. American speech in American Speech. English Today 4, 16-19.

FREUDENSTEIN, R. 1987. Hochschule und Schule im Dialog. Analyse einer fremdsprachlichen Verbandszeitschrift. Perspectives on Language in Performance. Ed. W. Löscher \& R. Schulze. Tübingen: Narr, 1-16.

GERLACH, P. 1988. Zeitschriftenforschung. Wiesbaden: Harrassowitz.

HENNING, G. 1986. Quantitative methods in language acquisition research. TESOL Quarterly 20, 701-708.

HEUER, H. 1986. Zitationsanalyse als Aspekt der Zeitschriftenforschung in der englischen Fachdidaktik: Eine empirische Untersuchung von Leitautoren und Konzepten. To appear in Kahl Festschrift.

KAHN, G. \& B. Sapin-Lignieres. 1982. Naissance de REFLET. Le Français dans le Monde 170, 23.

KERNDTER, F. 1988. Pour mieux connaître ... la France: la Vie du Rail. Zielsprache Französisch 20, 54-58.

LOHMANN, C. 1976. Der Englischunterricht im Spiegel seiner Fachzeitschriften. Kiel.

MATTHEY, F. 1967. La revue 'English Language Teaching’: vingt ans au service des maîtres d'anglais. Bulletin CILA 2, 68-70.

McGLONE, E.L. et al. 1985. The major research journals in foreign languages: a survey of heads of doctoral degree granting departments. The Modern Language Journal $69,1-7$.

MOIRAND, S. 1988. Une histoire de discours. Paris: Hachette Education.

MOLHOLT, G.G. 1981. Bibliographic database searching for EFL through the Saudi Arabian National center for Science and Technology (SANCST) computer system. TEAM 38, 19-21.

OTT'O, E. 1978. Periodika zum Bereich der 'Irish Studies'. Anglistik \& englischunterricht 6, 157-168.

OTTO, E. \& G. Stratman. 1977. Literatur in Wissenschaft und Unterricht. Anglistik \& englischuntericht 3, 201-208.

PERKINS, A.W. \& Chvany, C.V. 1987. Language pedagogy: the teaching of Russian. Slavic and East European Journal 31, 196-225.

SCHRöDER, J. 1985. Glottodidactica. An International Journal of Applied Linguistics, Adam-Mickiewicz-Universität Poznan, Bd. I-XV. Deutsch als Fremdsprache 22, 185187.

SPIEGEL, H.-R. 1988. Fachsprache - Internationale Zeitschrift für Fachsprachenforschung, - didaktik und Terminologie im 9. Jahrgang. Die Neueren Sprachen 87, 215-221.

STRECKER, B. 1978. Gibt es eine eigenständige Fachdidaktik Englisch für berufsbildende Schulen? Deutungsversuch im Spiegel einer Zeitschrft. Die Neueren Sprachen 77, 445-451.

SWALES, J. 1988. 20 years of the TESOL Quarterly. TESOL Quarterly 22, 151-163. 